\title{
INSTRUCCIONES PARA LOS VIVOS
}

Evelyn Gabriela Buitrago Espitia ${ }^{1}$ Luna Nicol Lozano Rivera ${ }^{2}$

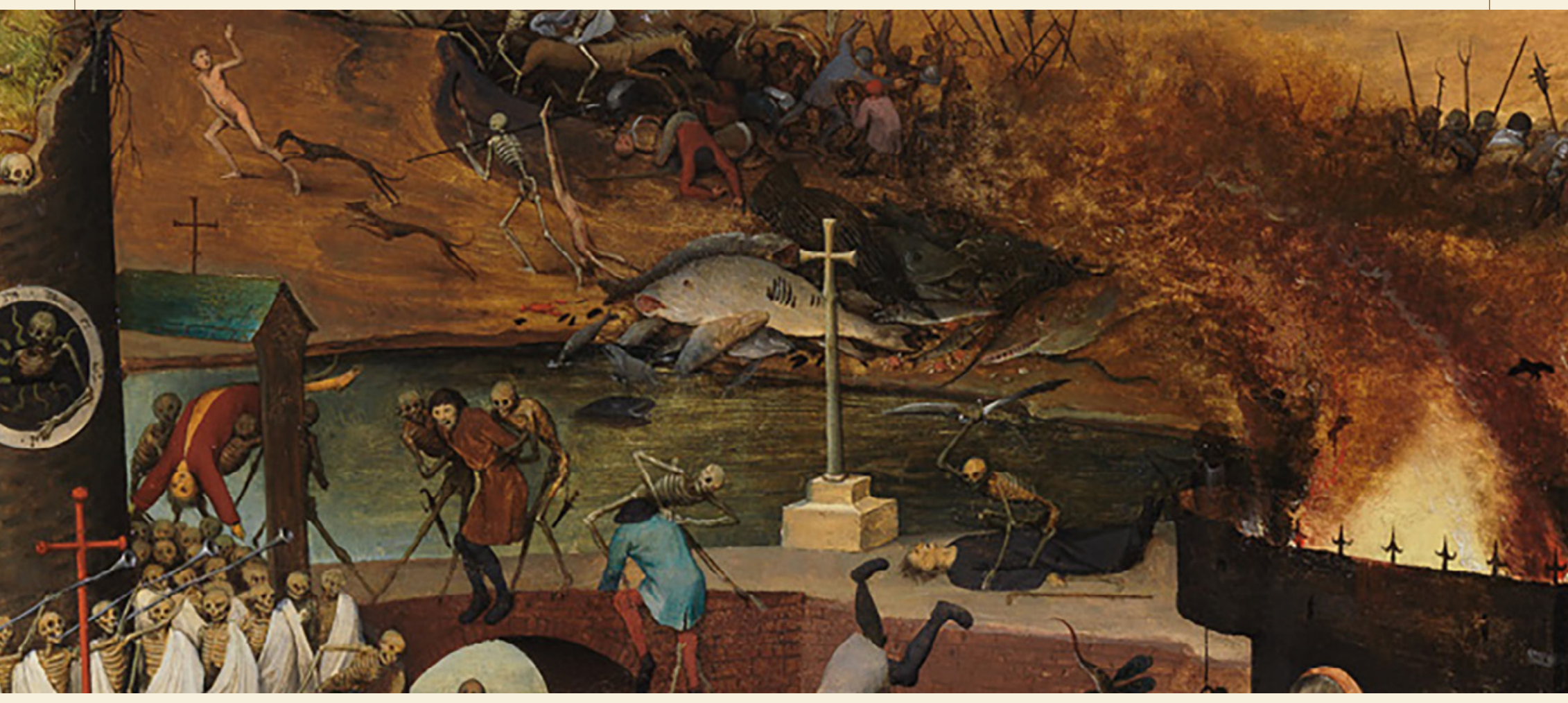

1 Estudiante de la Licenciatura en Humanidades y Lengua Castellana de la Universidad Distrital Francisco José de Caldas. Integrante del semillero de investigación Hermeneia. Correo electrónico: egbuitragoe@correo.udistrital.edu.co ORCID https://orcid.org/0000-0002-2909-5803

2 Estudiante de la Licenciatura en Humanidades y Lengua Castellana de la Universidad Distrital Francisco José de Caldas. Integrante del semillero de investigación Hermeneia. Correo electrónico: Inlozanor@correo.udistrital.edu.co ORCID https://orcid.org/0000-0002-1271-1745

Cómo citar: Buitrago Espitia, E. G., Lozano Rivera, L. N. (2020). Instrucciones para los vivos. Enunciación, 25(2, separata), IX-XI. https://doi.org/10.14483/22486798.17028 
Señor Cortázar, cordial saludo. Espero que de cuando en cuando haya terminado de vomitar todos los conejitos de colores que acompañaban sus noches y se encuentre bien desde la parte del mundo que habita. La presente es para expresarle nuestra preocupación por el surgimiento de un virus que nos ha puesto patas arriba. Aquí no se pueden dejar de lado los motivos, atengámonos a la amenaza del siglo, es decir, a la resurrección del miedo, ese miedo que cubre sonrisas y gestos con fina tela antifluida cual si fuera la túnica de la muerte. Meses atrás "cuidarse" consistía en perfeccionar nuestros rostros ante el espejo, cubrir la desnudez con pomposos harapos tal si fuéramos pavos, para finalmente asegurar

la proximidad con el otro; hoy día, el cuidado termina cuando las distancias se acortan y nacen las caricias. Por el contrario, debemos encerrarnos en casa, limpiar las suelas de los zapatos, rociar con

alcohol las prendas, lavar las manos durante 30 segundos con abundante agua y jabón. Si nos resulta, haremos de la imaginación nuestro espejo, pues, no hay más remedio, considerémonos caracoles en su concha... por tiempo indefinido.

Desde la tierra de Macondo Gabriela y Luna

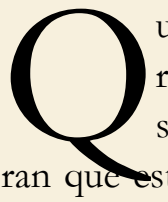
ueridos lectores, aunque quizá las cartas ya pasaron de moda, aquí lo que importa no es el medio sino el mensaje; por eso sus remitentes consideta carta no es solamente para Cortázar, es para todo aquel que por algún motivo se acercó a la revista Emunciación de la Universidad Distrital Francisco José de Caldas. Sí, se repite la historia y no existe momento más adecuado que este para entender las palabras de Camus (1999): "ya no había destinos individuales, sino una historia colectiva que era la peste y sentimientos compartidos por todo el mundo" (p.155). Basta con sustituir la carta, encender el televisor y prestar atención:

El coronavirus no es un juego [...] usa tapabocas en espacios sociales [...] mantén la distancia social y lávate las manos. Pero esperen un poco más, no se levanten y sigan prestando atención: -hoy más que nunca tu familia, tu comunidad y Colombia te necesitan [...] hoy prima la seguridad por eso nos quedamos en casa [...] quédate en casa, si te cuidas, cuidas a Colombia.

Pobre y triste televisor, las propagandas inundaron su ser hasta que se enfermó, empezó a transmitir como por inercia; sí, como un disco rayado. Ahora no solo a Sabines le preocupa el televisor "porque lo que tiene es una fiebre tremenda, un dolor de cabeza, una náusea horrible, que lo hacen soñar estas cosas que vemos". Propaganda va, propaganda viene -que me cuide, que te cuides, que nos cuidemos-; desdichado televisor, está cansado de propagar en su pantalla mensajes de una nueva realidad que aún no termina de comprender.

Es oficial, tuvimos que reconocer que en Macondo la llegada de la nueva peste fue inminente y que por el momento es irremediable. Cabe aclarar que en esta ocasión la peste llamada covid-19 no quita el sueño como sucedió en Macondo, ahora lo que quita el sueño sencillamente es tener que asumir esta realidad. Han pasado meses y vivimos cada día sin dejar de lado la sensación de haber sido declarados culpables y, aunque desconocemos el delito, sabemos muy bien de qué se trata la pena; somos pobres y enjaulados sujetos obligados a observar lo que parece ser el mundo desde una ventana parlanchina cuyo panorama uniforme y desalentador no permite divisar el cielo, ver los árboles, sentir el viento o dormir bien.

El insomnio se llevó la memoria, pero esta vez la solución no la pudo proponer José Arcadio. En su lugar, fue propuesta por quienes encontraron en el televisor la herramienta para suplir el calendario y poder recordar lo importante. Ahora, parece que si queremos vivir, estaremos condenados a escuchar el eco de esas voces como mínimo una hora al día; en los noticieros y propagandas que se dedican a pregonar verdades sin descanso para que los vivos nos escabullamos de la muerte.

Los pobres y cansados oídos quisieran que, por un milagro, el televisor dejara de transmitir y de repente aparezcan el canto de los pájaros y el briznar de las pequeñas gotas que torpemente chocan contra el paraguas. Pero eso no es todo, pobres orejas, echadas hacia adelante cargando como si fuera parte de ellas un lazo que las lleva como a los 
perritos cuando pasean... Pobres y resecas manos, la cirrosis se ha vuelto común en ellas, los hígados descansaron; pues los alcohólicos ya no son ellos, antes bañábamos nuestras prendas con perfumes de rosas y jazmines; ahora nos rociamos con alcohol industrial como si fuera la esencia de Coco Chanel.

Parece que la pena que nos ha sido atribuida va más allá del suplicio, nuestros cuerpos no solamente son controlados, han perdido sus voces y son sumisos ante esa máquina parlanchina, cuyo objetivo es manipular nuestros pensamientos. El biopoder de Foucault ha trascendido hasta llegar al inconsciente; el psicopoder de Byung Chul Han llegó para marcar un precedente; poco a poco adquirimos nuevos hábitos, los hacemos de manera mecánica y los medios no dejan olvidar el porqué; cuidarme, cuidarte, cuidarnos.

Sin embargo, es una pena que la realidad transmitida por el televisor pocas veces corresponda con lo que experimentamos al cruzar la puerta y caminar por unas cuantas calles; la distancia mínima no existe, los tapabocas quedan atrapados en los bolsillos de los pantalones o cubren descaradamente el cuello, mientras las narices y las bocas pasean libremente por los parques. Por eso, a pesar del eco de las voces, lo que entra por un oído, sale por el otro. En Macondo los oídos son caprichosos, son tercos como aquel que los posee, se niegan a hacer caso a la idea que se repite una y otra vez en sus mentes por culpa del televisor. Pero recuerden:

Y lo que yo diga ahora de mi, lo digo de ti, porque lo que yo tengo lo tienes tú $y$ cada átomo de mi cuerpo es tuyo también.

Whalt Whitman, Canto a mí mismo.

\section{Referencias}

Camus, A. (1999). La peste. Buenos Aires: Editorial Sudamericana. 